\title{
BMT Sebagai Penunjang Perekonomian Usaha Kecil Menengah
}

\author{
Dadang Sudrajat \\ Sekolah Tinggi Agama Islam Negeri (STAIN) Sorong \\ Email : dadangsudrajat.da@gmail.com
}

\section{PENDAHULUAN}

Semakin berkembangnya kehidupan sekarang ini maka tingkat kebutuhan primer, sekunder, serta tersier akan ikut meningkat pula. Hal ini menimbulkan semakin banyaknya usaha kecil bermunculan guna memenuhi kebutuhan yang krusial. usaha kecil adalah usaha ekonomi produktif yang berdiri sendiri, yang dilakukan oleh orang per orang atau badan usaha yang bukan merupakan anak perusahaan atau bukan cabang perusahaan yang dimiliki, dikuasai, atau menjadi bagian baik langsung maupun tidak langsung dari usaha menengah atau usaha besar yang memenuhi kriteria usaha kecil sebagaimana dimaksud dalam undang-undang Nomor 20 Tahun 2008 Bab 1 Pasal 1 tentang UKM (Arif Yusuf Hamali, 2016).

Menurut Sriyatun, Disisi lain kemampuan pengusaha kecil mempunyai mempunyai berbagai kelemahan terutama dalam tiga hal yaitu manajemen, skill dan finansial (Fitriani Prastiawati \& Emile Satia Darma, 2016). Permodalan merupakan penunjang dari keberlangsungan suatu usaha baik lingkup makro maupun mikro. Hal yang menjadi masalah dalam dunia usaha kecil ini yaitu dari segi permodalan karena dari pihak Bank tidak dapat memenuhi kebutuhan permodalan dari para pengusaha kecil karena dianggap tidak memenuhi kriteria dalam pengajuan pinjaman. Dengan adanya permasalahan permodalan yang tidak dapat terpenuhi oleh lembaga keuangan Bank memicu adanya persaingan pada lembaga keuangan non Bank konvensional maupun lembaga keuangan non Bank syariah guna mendapatkan nasabah atau anggota.

Lembaga keuangan syariah non Bank yang menyalurkan dana kepada masyarakat adalah BMT (Baitul Maal Wa Tamwil) dengan menggunakan sistem keuangan yang sesuai dengan syariah. Dalam operasionalnya BMT tidak saja berperan menyalurkan dana kepada masyarakat yang mampu dari segi finansial dan jaminan namun menyalurkan juga dana kepada masyarakat yang tidak mampu dari segi finansial tetapi dengan syarat memenuhi kriteria tertentu. Dengan adanya lembaga keuangan non Bank maka dapat menjangkau 
lapisan masyarakat pengusaha kecil menengah dari segi permodalan.

\section{BAITUL MAAL WAT TAMWIL (BMT)}

BMT adalah kependekan kata Balai Usaha Mandiri Terpadu atau Baitul Maal Wat Tamwil, yaitu lembaga keuangan mikro (LKM) yang beroperasi berdasarkan prinsip-prinsip syariah. BMT sesuai namanya terdiri dari dua fungsi utama, yaitu:

1. Baitul tamwil (rumah pengembangan harta), melakukan kegiatan pengembangan usaha-usaha produktif dan investasi dalam meningkatkan kualitas ekonomi pengusaha mikro dan kecil dengan antara lain mendorong kegiatan menabung dan menunjang pembiayaan kegiatan ekonomi.

2. Baitul maal (rumah harta), menerima titipan dana zakat, infak dan sedekah serta mengoptimalkan distribusinya sesuai dengan peraturan dan amanahnya produkproduk BMT (Andri Soemitra, 2009).

\section{PENDIRIRAN DAN PERMODALAN BMT}

1. Pendirian BMT

BMT dapat didirikan oleh:

a. Sekurang-kurangnya 20 orang.

b. Satu pendiri dengan yang lainnya tidak memiliki hubungan keluarga.

c. Sekurang-kurangnya $70 \%$ anggota pendiri bertempat tinggal disekitar daerah kerja BMT.

d. Pendiri dapat bertambah dalam tahun-tahun kemudian jika disepakati oleh rapat pendiri.

2. Permodalan BMT

a. Simpanan pokok (SP) yang ditentukan besarnya sama besar untuk semua anggota.

b. Simpanan Pokok Khusus (SPK) yaitu simpanan pokok yang khusus diperuntukkan untuk mendapatkan sejumlah modal awal, sehingga memungkinkan BMT melakukan persiapan-persiapan pendirian dan memulai operasinya. Jumlahnya dapat berbeda antar anggota pendiri (Esti Setyorini, 2017). 


\section{PRODUK-PRODUK BMT}

1. Produk penghimpunan dana terdiri dari :

a. Simpanan modal (simpanan pokok khusus, simpanan pokok, simpanan wajib).

b. Simpanan Mudharabah (simpanan umum produktif, simpanan persiapan, investasi berjangka, investasi berkah, investasi peduli).

c. Simpanan wadi'ah (amanah).

d. Arisan Ta'awun Syariah (ARTA Syar'i)

e. Zakat, Infaq, Shadaqah.

2. Pembiayaan

a. Kerjasama Usaha (Musyarakah).

b. Modal kerja usaha (Mudharabah).

c. Jual beli (Murabahah).

d. Sewa menyewa (ljarah).

e. Pinjaman kebaikan (Qardhulhasan) (Heri Saputra, 2013).

\section{PRINSIP-PRINSIP BMT}

1. Keimanan dan ketakwaan kepada Tuhan Yang Maha Esa dengan mengimplementasikan prinsip-prinsip syariat dan muamalat Islam ke dalam kehidupan nyata.

2. Keterpaduan (kaffah), yaitu nilai-nilai spiritual berfungsi mengarahkan dan menggerakkan etika dan moral yang dinamis, proaktif, progresif, adil, dan berakhlak mulia.

3. Kekeluargaan/koperasi.

4. Kebersamaan.

5. Kemandirian. 
6. Profesionalisme.

7. Istiqamah: konsisten, konsekuen, kontinuitas/berkelanjutan tanpa henti dan tanpa pernah putus asa (Azyumardi Azra, 2003).

\section{FUNGSI BMT}

1. Menjauhkan masyarakat dari praktek ekonomi non-syariah.

Aktif melakukan sosialisasi di tengah masyarakat tentang arti penting sistem ekonomi Islami. Hal ini bisa dilakukan dengan pelatihan-pelatihan mengenai caracara bertransaksi yang Islami.

2. Melakukan pembinaan dan pendanaan usaha kecil.

BMT harus bersikap aktif menjalankan fungsi sebagai lembaga keuangan mikro.

3. Melepaskan ketergantungan pada rentenir.

Masyarakat yang masih tergantung rentenir disebabkan rentenir mampu memenuhi keinginan masyarakat dalam memenuhi dana dengan segera.

4. Menjaga keadilan ekonomi masyarakat dengan distribusi yang merata.

Fungsi BMT langsung berhadapan dengan masyarakat yang kompleks dituntut harus pandai bersikap, oleh karena itu langkah-langkah untuk melakukan evaluasi dalam rangka pemetaan skala prioritas yang harus diperhatikan (Jajang Nurjaman, 2010).

\section{MANFAAT BMT}

Sebagai lembaga pengelola dana masyarakat dalam sekala kecil dan menengah, menawarkan pelayanan jasa dalam bentuk kredit dan pembiayaan kepada masyarakat. Beberapa manfaat yang dapat diperoleh dari pelayanan BMT menurut Suhendi, antara lain:

1. Meraih keuntungan bagi hasil dan investasi dengan cara syariah.

2. Pengelolaan dana berdasarkan nilai-nilai kejujuran dan keadilan akan menjadikan setiap simpanan dan pinjaman di BMT aman baik secara syar'i maupun ekonomi.

3. Komitmen kepada ekonomi kerakyatan, dimana BMT membuat setiap transaksi 
keuangan, memperoleh kredit dan pengelolaannya bermanfaat bagi pengembangan ekonomi umat Islam.

4. BMT dan masyarakat dapat berperan membangun citra perekonomian yang dikelola umat Islam.

5. Menggairahkan usaha-usaha produktif dan membebaskan mereka dari jeratan rentenir.

6. Partisipasi positif bagi kemajuan lembaga-lembaga keuangan dan perbankan Islam termasuk di dalamnya BMT (Rini Hayati Lubis, 2015).

\section{SISTEM PEMBIAYAAN BMT}

Menurut Antonio pembiayaan merupakan salah satu tugas BMT, yaitu pemberian fasilitas penyediaan dana untuk memenuhi kebutuhan pihak-pihak yang merupakan defisit unit. Menurut sifat penggunaannya, pembiayaan dapat dibagi menjadi dua hal yaitu:

1. Pembiayaan produktif, yaitu pembiayaan yang ditunjukkan untuk memenuhi kebutuhan produksi dalam arti luas.

2. Pembiayaan konsumtif, yaitu pembiayaan yang digunakan untuk memenuhi kebutuhan konsumsi.

Menurut keperluannya, pembiayaan produktif dapat dibagi menjadi dua hal berikut:

1. Pembiayaan modal kerja, yaitu pembiayaan untuk memenuhi kebutuhan.

2. Pembiayaan investasi, yaitu untuk memenuhi kebutuhan barang-barang modal (capital goods) serta fasilitas-fasilitas yang erat kaitannya dengan itu (Fitra Ananda, 2011).

\section{PROSEDUR PEMBIAYAAN BMT}

1. Nasabah datang ke BMT untuk mengajukan permohonan pembiayaan. Disini nasabah mengajukan jumlah pembiayaan yang diinginkan kepada BMT.

2. Setelah pengisian aplikasi permohonan, maka selanjutnya melengkapi data persyaratan pembiayaan. Adapun kelengkapan dokumen yang perlu dipenuhi ketika nasabah ingin mengajukan pembiayaan di BMT yaitu:

a. Foto copy KTP suami-istri (yang sudah berkeluarga). 

b. Foto copy KTP orang tua (yang belum berkeluarga).
c. Foto copy Kartu Keluarga (KK).
d. Foto copy surat nikah.
e. Anggota dan calon anggota yang tidak memiliki KTP yang berlaku, harus dilengkapi dengan surat keterangan bukti diri dari daerah setempat.

f. Menyerahkan foto copy jaminan.

3. Setelah semua dipenuhi, pihak BMT akan melakukan analisis secara administratif dan melakukan survei apabila diperlukan. Analisa yang dilakukan adalah 6 pilar.
a. Watak (caracter).
b. Kemampuan (capacity).
C. Modal (capital).
d. Jaminan (collateral).
e. Kondisi (condition).
f. Syariah.

4. Setelah administratif dan survei, kemudian dirapatkan oleh bagian pembiayaan untuk kelayakan pembiayaan tersebut.

5. Apabila pembiayaan telah disetujui oleh pihak yang berwenang, maka selanjutnya BMT melakukan akad/kontrak perjanjian dengan pihak nasabah yang juga disertai pengikatan jaminan kemudian pencairan dana.

6. Ketika akad telah ditandatangani, maka kewajiban nasabah terhadap BMT dimulai, yaitu membayar angsuran dengan besaran yang ditentukan dan jangka waktu yang telah disepakati dalam perjanjian.

7. Kemudian penyelesaian apabila terjadi pembiayaan bermasalah diselesaikan berdasarkan fatwa Dewan Syariah Nasional Majelis Ulama Indonesia (Aswad Addu Ali Humad Al Alim, 2015).

\section{PENUTUP}

BMT sebagai lembaga keuangan syariah non Bank memiliki andil yang besar dan 
berkontribusi dalam perekonomian usaha kecil menengah. Peran yang dilakukan BMT sebagai wadah alternatif dalam hal keuangan yaitu simpan pinjam dan juga sebagai mitra kerja telah mampu menumbuhkan tingkat perekonomian dengan respon positif baik secara moril maupun materil. Hal ini ditunjukkan dengan kondisi di lapangan bahwa para pengusaha kecil telah mempercayakan dana kepada BMT untuk dikelola dalam rangka membantu dan meningkatkan perekonomian serta produktivitas dari para pelaku ekonomi mikro. Peran serta keberhasilan yang telah dicapai BMT maka layak diperhitungkan sebagai alternatif sebuah lembaga keuangan yang terpercaya dalam arus perekonomian modern guna meningkatkan ekonomi rakyat. 


\section{DAFTAR PUSTAKA}

Al Halim, A. A. A. H . Analisis Prosedur Pembiayaan dan Dampaknya Terhadap Kepuasan Nasabah (Studi Kasus Di BMT Tumang, BMT Anda, BMT Al Ishlah di Kota Salatiga). Skripsi.

Ananda, F. (2011). Analisis Perkembangan Usaha Mikro dan Kecil Setelah Memperoleh Pembiayaan Mudharabah Dari BMT At Taqwa Halmahera di Kota Semarang. Skripsi.

Arif, H .Y . (2016). Pemahaman Strategi Bisnis dan Kewirausahaan. Deepublish.

Azra, A. (2003). Berderma Untuk Semua. Deepublish.

Hubis, R. H. (2015). Peranan Baitul Mal Wat Tamwil Terhadap Perekonomian Sumatera Utara. Jurnal Al-Masharif Volume 3, No. 2, Juli-Desember.

Nurjaman, J. (2010). Peranan Baitul Maal WatTamwil Dalam Mengatasi Dampak Negatif Praktek Rentenir. Skripsi.

Prastiawati, F; \& Darma, E. S. (2016). Peran Pembiayaan Baitul Maal Wat Tamwil Terhadap Perkembangan Usaha dan Peningkatan Kesejahteraan Anggotanya dari Sektor Mikro Pedagang Pasar Tradisional: Jurnal Akuntansi dan Investasi.

Saputra, H. (2013). Strategi Penyelesaian Pembiayaan Bermasalah di KJKS BMT Syariah Sejahtera Boyolali Naskah Publikasi. Jurnal.

Setyorini, E. (2017). Mekanisme Pembiayaan Rahn Di BMT Marhamah Wonosobo. Skripsi. Soemitra, A. (2009). Bank \& Lembaga Keuangan Syariah. Deepublish. 